\title{
ESD through Technology Education: Contextualisation of Approaches
}

\author{
Margarita Pavlova \\ Griffith Institute for Educational Research \\ Griffith University, Mt. Gravatt, Queensland, Australia \\ m.pavlova@griffith.edu.au
}

\begin{abstract}
The importance of addressing education for sustainable development (ESD) through technology education has been argued by a number of researchers; it appears increasingly in curriculum document statements; and some resources have been developed for use by teachers. However, when the concept of sustainable development is discussed within technology education it is mainly focused on the ecological design of products with a major emphasis on limiting the environmental impacts of those products. This article examines the nature of sustainable development and argues for the basis of ESD in technology education. The ethics of weak anthropocentrism and a focus on the human condition are suggested as a guiding framework for the underlying philosophy of technology education. Value change and technical fix are proposed as interlinked approaches for the development of learning activities. The article proposes some applications of the above principles in technology education classrooms. Environmental and social emphases are identified as possible priorities within different contexts. The argument was supported by the UNEP analysis of challenges confronting countries internationally in terms of reducing per capita ecological footprint or increasing the human development index. Examples of classroom activities illustrate how the above differences could be addressed in the classroom.
\end{abstract}

Key words: transformative pedagogy, ESD in technology education, ethics of ESD, contextualised approaches to ESD, ESD activities in technology education

\section{Introduction}

At the heart of Teacher professional knowledge is a personal subject construct that results from the dynamic relationships between pedagogical and subject knowledge and context-specific knowledge (e.g. school/community relations) (Cochran, DeRuiter \& King, 1993). Teacher's subject knowledge is enhanced by their understanding of pedagogical practices and by the contextual frameworks relevant to a particular school. The personal construct is also framed by past experiences, of learning and personal beliefs about the purpose of the subject. 
ESD through Technology Education: Contextualisation of Approaches

In 2005 at the International Technology Education Association (ITEA) 67th Annual Conference, 30 academics were asked to write down their definition of technology education. As a result, 30 different definitions were produced. The author's definition is presented below:

Technology education is a learning area that provides an opportunity for students to understand the nature of technology and its relationships with society and the environment, and to design and make products and systems in accord with the principles of sustainable development which take into account different dimensions of development such as social, economic and environmental.

Through their studies students are encouraged to explore human needs and respond by using technology to transform materials, information and energy. Student-centred teaching strategies help students to develop personal qualities such as responsibility towards the current world and future generations, the ability to solve problems, demonstrate initiative and acquire appropriate skills and knowledge. Technology education should also be fun!

For the author the essence of technology education is to involve students in learning through designing and making products and systems within the framework of sustainable development. This article examines the nature of sustainable development and argues for the basis of ESD in technology education. The ethics of weak anthropocentrism and a focus on the human condition are suggested as a guiding framework for the underlying philosophy of technology education. Value change and technical fix are proposed as interlinked approaches for the development of learning activities. The second part of the article presents some applications of the above principles in technology education classroom.

\section{Sustainable Development as a Concern for Human Condition}

The policy discourses on education for sustainable development (ESD) and environmental education (EE) were initially constructed by policy-makers through a number of international conferences and summits. Since the Biosphere Conference in 1968 (Paris), the UN system, in particular the UNESCO and United Nations Environment Programme (UNEP), have played an important part in the development of EE and later ESD in answer to current global problems. This development includes progression in theoretical, methodological and social adjustments to the discourse over the period of four decades. The historical progressions demonstrate that in the international arena discussions of the environment developed from a somewhat narrow, nature-oriented focuses (UNESCO, 1969) to broader interpretations that included, social, political and economic aspects and their interdependence (UN, 1972). However, development was mostly interpreted in economic terms. The environment was the focus of attention. 
Building on such benchmarks as the report of the Brundtland Commission on Environment and Development (United Nations, 1987), the process of change in interpretations of environment-development relationships was encapsulated in the first principle of the Rio Declaration on Environment and Development (United Nations, 1992). This proclaimed that people are the focus of concerns for sustainable development, and are entitled to a productive relationship with nature. The document reinforced the message that developmental and environmental needs should be considered as integral components of the process of development. Therefore the document represents another step in the process from 'development' and 'environment' being considered separately to their combination in 'sustainable development'. A concern for the human condition was also linked to economic development that was viewed only as a contributing factor for human development, and not an end in itself. The current model of the market economy has been questioned as, under this model, neither the environment nor half the world's population benefit (UNESCO, 2006). Therefore there is a need to search for different economic models that can contribute to SD and that include reduction of excessive wealth, more equitable distribution of it and care for the environment.

Thus, a concern for the human condition, in addition to environmental condition, is now truly present in the political SD agenda. Economic development is increasingly viewed as a means of contributing to human development, and not an overarching goal. UNESCO emphasized that poverty reduction, although the focus of the economic aspect of sustainable development, needs to be considered in relation to the social, environmental, and cultural aspects (UNESCO, 2006).

\section{Transformative Pedagogy}

More than three decades separate the times when environmental education (EE) and then education for sustainable development (ESD) emerged as educational agendas on the international arena. These three decades have been associated with significant shifts in the educational debate on the purpose and nature of education and with the need to face crises caused by the modern idea of progress. Scientists from different fields warn humanity that the current trajectory of capitalism is leading towards environmental and cultural decline (e.g., EarthTrends, 2008; Population Action International, 2008; Worldwatch Institute, 2008) and that urgent measures are required to deal with the current and emerging issues. Global financial and economic crises, poverty and inequality, climate change and environmental degradation reinforce our understanding that a collaborative effort is required in addressing the existing status quo through education.

Concern over the need to develop a planetary vision that enables people to see the interconnectivities of the world and the need to address issues holistically is an old one. This understanding goes back to the very beginning of the $20^{\text {th }}$ century, when Vladimir Vernadsky developed a theory of the nöosphere that presented a philosophically rethought image of our desirable future, one that in current 
ESD through Technology Education: Contextualisation of Approaches

terminology is called a sustainable future. Vernadsky's concept of nöosphere or the "sphere of wisdom" (tsarstvo razuma) is grounded in his research in the physical sciences and stages in the evolution of the planet (Vernadsky, 1926, 1945, 1998) from a geological perspective. Although our species represents an insignificant mass of the planet's matter, humankind has emerged as the increasingly dominant "geological force" in the biosphere:

Its strength is derived not from its matter, but from its brain [italics added]. If man understands this, and does not use his brain and his work for selfdestruction, an immense future is open before him in the geological history of the biosphere. (Vernadsky, 1945, p. 5)

That force is defined not simply by the biological metabolism of the human population (such as its nutrition, excretion, and muscular effort) but by the much larger flows of matter and energy, which are connected with the physical-economic activity of human society:

Mankind taken as a whole is becoming a mighty geological force. There arises the problem of the reconstruction of the biosphere in the interests of freely thinking humanity as a single totality. This new state of the biosphere, which we approach without our noticing, is the nöosphere. (Vernadsky, 1945, p. 5)

Vernadsky believed that nöosphere is the last stage in the evolution of the biosphere in geological history. The concept of nöosphere provides a useful contribution to the formation of a new global and holistic worldview, which envisages a world where human consciousness, cognitive power and wisdom help to harmonize a co-existence of humanity and nature. Vernadsky argued that all components of human nature such as our mind (through appropriate information and knowledge), heart (through feelings and emotions), and spirit (through the highest human aspirations and morals) should be reached and moved in the process of nöosphere development.

Now we are at the next phase when the argument that human consciousness is the way to solve problems that our planet faces, has gained more support (e.g., Beck, 1994, 1997; Giddens, 1990,1994a, 1994b - reflexivity; Gardner, 2001 - conscious agents; Bonnett, 2002 - frame of mind; Sterling, 2007 - a positive planetary vision; Hart, 2008 - consciousness as a viable concept). Bonnett, for example, directly locates the essence of sustainability in the nature of human consciousness -emphasizing the special position that human consciousness ('a frame of mind') has in "the greater scheme of things" and suggests that sustainability seeks and requires openness to nature.

If sustainability as a frame of mind addresses fundamental issues of the meaning of life, education needs to play a transformative role, challenging the assumptions and beliefs within our societies that have led to the current social, environmental and economic crises. ESD requires the most radical, 'transformative' pedagogy. It should be focused on the process of learning to "live within ecological limits without human 
suffering [and] must include uncovering the ideologies and power relationships that underlie the discourses of sustainable development" (Stevenson, 2006, p. 287).

Sterling (2001) believes that while education remains dominated by modern forms of knowledge and pedagogy, it cannot promote sustainability. There is a need for a new education that addresses social issues and facilitates critical thought regarding conflicts of interest (Argyris \& Schön, 2004). This new education should lay the groundwork for a "change in the values of theory-in-use" and for educating active, constructive and oppositional citizens who can question the basis of the existing system (Sterling, 2004, p. 65). In line with this perspective, where critical theory could be one of the points of departure, education should be analysed not only in terms of how it reproduces existing social practice, but also in terms of "its potential to nurture moral courage and constructive opposition" (Lundegård \& Wickman, 2007 , p. 2). Different visions of society, such as "eco-effective welfare society" as it is termed in Finland (Finnish National Commission on Sustainable Development, 2006), or "noorsphere vision of the future" as it is conceptualized in Russia (Vernadsky, 1945), can help to re-orient education. We want to engage people in learning about ideas that contribute to reimaging existing worldviews and to reconsider the relationships between people and the planet.

\section{Education Basis for ESD Pedagogy in Technology}

ESD could be an effective way of contributing towards this transformative education establishing sustainable livelihoods.

\section{Ethics behind ESD}

Throughout the history of humanity, the relationship between humanity and nature has been among the most important existential and philosophical issues. In traditional cultures the unity of humanity and nature has been presented within an overall perception of the world; some indigenous cultures still preserve this view. Through historical development, particularly in the West, technological development and an increase in technocratic ideology, linked with the expansion of human power through technical control (Habermas, 1968/1971), has greatly contributed to environmental and social problems and, as a consequence, to the emergence of a discourse about SD.

The differences in views of the relationship between humanity and nature are partly rooted in different philosophical and moral conceptions of appropriate ways to conceptualize these relationships. On the opposite sides of the debate are ecocentric environmental ethics and 'deep ecology' (which attribute intrinsic value to nature and suggest that humans should live according to nature), and anthropocentric or technocratic environmental ethics (which attribute instrumental value to nature and suggest that humans should use and manage nature wisely). Both positions have been criticized. Huckle (2006) argues that: 
ecocentrism can be criticised in that it romanticises a nature outside society and fails to recognise that only humans can value things. Strong anthropocentrism/technocentrism can also be criticised in that it sanctions the exploitation and oppression of nature by treating it instrumentally or merely as a means to human ends. (p. 19)

So, in interpreting SD, a central question is: Should we put more emphasis on nature or humanity? Or, is there an appropriate balance?

There are a number of positions that advocate particular approaches to finding the required balance. Vernadsky's (1945) nöosphere and Bonnett's (2002) 'frame of mind' positions are two examples. Both positions focus on human consciousness (which constitutes an important part of the value domain) and refer to the 'intrinsic valuing of persons' and harmony with nature as the superordinate goals. Their approaches can be positioned within the concept of weak anthropocentrism, the environmental ethic that promotes the mutual flourishing of human and non-human nature (for a full discussion see Pavlova, 2009). The underlying idea is that while "humans are the only source of value, they are not the only bearers of value" (Huckle, 2006, 19). It is essential to have a non-instrumental approach towards human and non-human nature. Therefore, an essential part of human consciousness relates to recognition of the value of the 'other'.

Weak anthropocentrism, for example, characterizes the founding principle formulated in the 'Caring for the Earth' strategy of IUCN, UNEP and WWF (1991) Among the nine principles for Sustainable Living formulated in the strategy, one provides the ethical base for all the others: Respect and care for the community of life, meaning duty to care for other people and other forms of life now and in the future.

Therefore, a conceptualization of sustainable development within a framework of weak anthropocentrism/nöosphere wisdom/'frame of mind' paradigm, which involves valuing of the 'other' (human and non-human), can provide a basis for the development of pedagogical approaches within ESD in technology education.

\section{Approaches for development of learning activities}

Robinson (2004) identified 'technical fix' and 'value change' as two major approaches towards solving problems caused by human-nature relationships. Although ESD put value change in the centre, it also places a strong emphasis on technical fix. UNESCO, for example, states that technology must be used in accordance with the goals of sustainability. Attempts to protect the environment and at the same time provide for economic development may be thwarted by the misuse of technology for the purpose of economic growth only (UNESCO, 2006). Therefore, although technology has positive features that can be used for SD of the world, currently its major aim is profitability: the majority of enterprises invest "not in order to benefit humanity or to protect it from problematic side-effects, but rather to open 
up markets and areas of expansion with promise to the future" (Beck, 1997, p. 117). It is argued here that this 'technical fix' approach should be used with caution. Analyses of technology (Beck, 1997; Ellul, 1987/1990) demonstrate that technology cannot fix the problems of the modern world alone. A 'technical fix' might treat only the symptoms, not the disease and root causes. Such terms as green economy (in a narrow sense) or industrial ecology do not represent a sufficient response to the challenge of the modern world, because reductions in the environmental impacts of national economies do not necessarily translate into improvements in the quality of life for all. Rather, to achieve changes towards sustainability, a 'value change' is required. A fundamental change in underlying values and attitudes that would characterize a radical shift in our thinking is part of the transformative journey for achieving sustainability.

Technology education is well positioned to apply both approaches (technical fix and value change) framed by the ethics of weak anthropocentrism. Principles of lifelong learning, interdisciplinarity, inclusion of social, environmental and economic realms, use of a variety of pedagogical techniques that promote participatory learning, development of higher order thinking skills, strong emphasis on local needs, and capacity building of communities as advocated by the International Implementation Scheme (UNESCO, 2005) provide more specific guidelines for teachers.

\section{Classroom applications}

\section{Two challenges}

Although for all countries the rationale for technology education needs to be framed by concern for the human condition, due to contextual differences the emphasis of technology education activities will vary. In a simplified way, for developed countries the major area of attention is related to environmental aspect of sustainable design. For developing countries, social aspects of sustainable design need to be emphasised.

This approach is justified by the analysis conducted by UNEP (2011) that used country's natural and human capital and its relative level of development as indicators to identify specific challenges. Two dimensions of this analysis are Ecological footprint as an instrument to measure the impact of our lifestyle on the environment and the Human Development Index (HDI) as an indicator of health, education, and standard of living. Figure 1 illustrates that some countries have attained high levels of human development, although at the expense of the quality of their environment. Other countries although maintaining relatively low per capita ecological footprints, need to improve levels of services and material well-being to their citizens. Therefore these two groups of countries have different challenges. The first one needs to reduce their per capita ecological footprint without impairing their quality of life; the second one needs to improve the well-being of their citizens 
without drastically increasing their ecological footprints. One of these two challenges affects every technology education classroom internationally.

\section{Figure 1: Sustainable development targets for developed and developing countries}

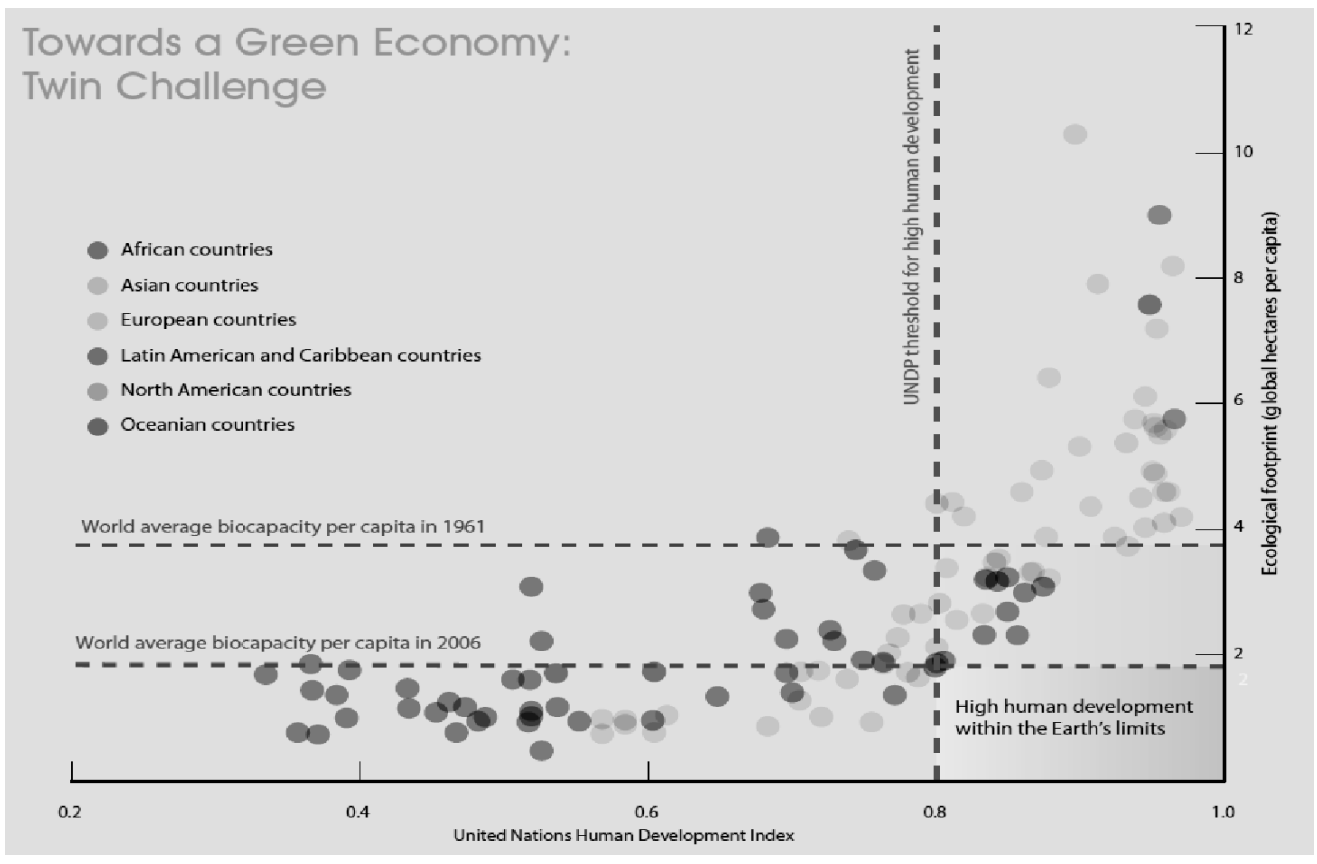

Note: While it is difficult to see the exact position of different countries in a grayscale figure, the spread between countries is easy to observe.

Source: The Ecological Wealth of Nations: Earth's Biocapacity as a New Framework for International Cooperation. Global Footprint Network (2010), p.13; Human Development Index data from Human Development Report 2009- Overcoming Barriers: Human Mobility and Development. UNDP (2009), Taken from: UNEP (2011).

\section{Examples of activities}

This section refers to a number of activities that could have different emphasises depending on the context. Low cost product design to improve peoples' quality of life, solving community problems through technology, use and revamp of traditional technologies could help to improve social well-being of local communities. Ecodesign and green manufacturing practices could be viewed as focused on limiting the environmental impact of products. 


\section{Low-Cost Products}

Project based learning is one of the important teaching tools that provides an excellent opportunity for realising ESD. Design projects involve students in the process of formulating tasks, undertaking research and the development and evaluation of ideas, their presentation and realisation. The creation of low-cost products, designed to make life better for people where the primary concern for the students is the social aspect of sustainability, could provide an important emphasis for students' activities. Some real life examples such as solar-powered housing units built from re-used shipping containers to provide housing for disaster victims; the Hippo Water Roller, a rolling 90-litre drum made of lightweight, durable polyethylene and pushed by a simple handle to help people with water supply; an under \$100 wind-up computer; cheap devices to purify water (Marashian, 2006) could be used as prompts to stimulate students' thinking. They could be used as objects for a product analysis activity when students are exploring the social dimension of sustainability and generating ideas for their projects.

Solving community problems through technology systems

Application of systems could help students to solve some community problems. An example below presents a systematic view of a problematic issue. As illustrated by Figure 2, system-based, closed loop thinking provides an opportunity for a great community based design and technology project: a farming system that exists without any fossil fuel input that does not produce waste.

The Biogas anaerobic digester takes in livestock manure plus wastewater, and generates biogas, which provides all the energy needs for heating, cooking and electricity. The partially cleansed wastewater goes into the algal basin where the algae produce by photosynthesis all the oxygen needed to detoxify the water, making it safe for the fish. The algae are harvested to feed chickens, ducks, geese and other livestock. The fishpond supports a compatible mixture of 5-6 fish species. Water from the fishpond is used to 'fertigate' crops growing in the fields or on the raised dykes. Aquaculture of rice, fruits and vegetables can be done in floats on the surface of the fishpond. Water from the fishpond can also be pumped into greenhouses to support aquaculture of fruits and vegetables. The anaerobic digester yields a residue rich in nutrients that is an excellent fertiliser for crops. It could also be mixed with algae and crop residues for culturing mushrooms after steam sterilisation. The residue from mushroom culture can be fed to livestock or composted. Crop residues are fed back to livestock. Crop and food residues are used to grow earthworms to feed fish and fowl. Compost and worm castings go to condition the soil. Livestock manure goes back into the 
anaerobic digester, thus closing the grand cycle. The result is a highly productive farm that's more than self sufficient in food and energy ${ }^{1}$.

\section{Figure 2: Dream Farm}

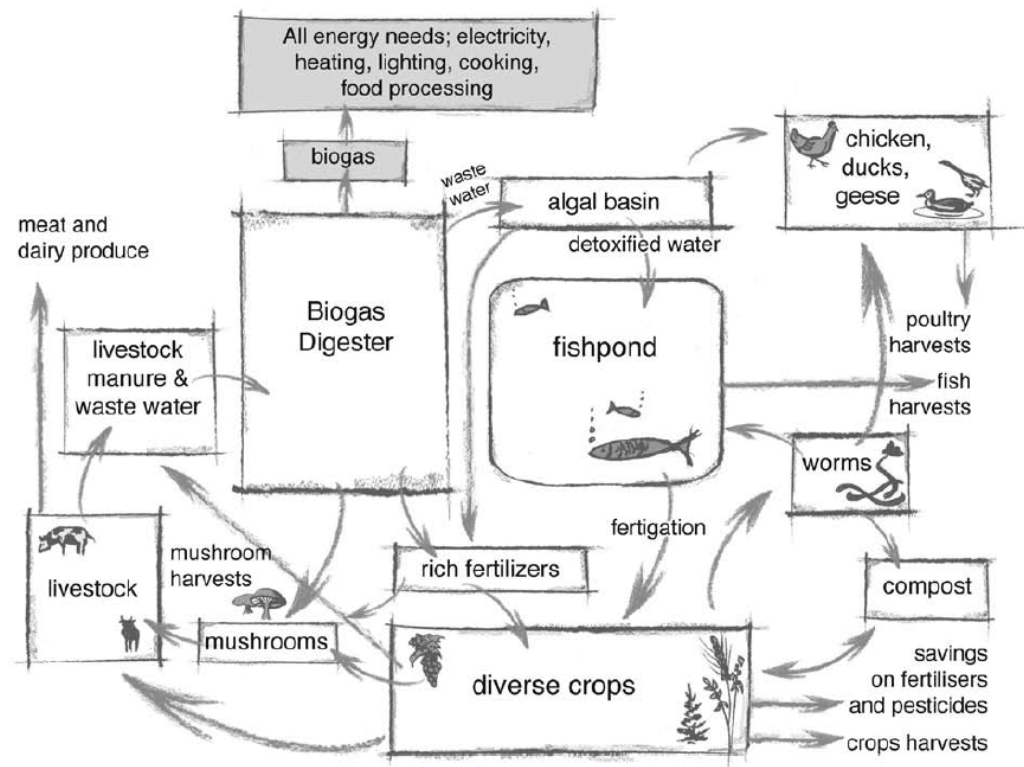

Source: Webster \& Johnson (2008). Sense \& Sustainability: Educating for a low carbon world. TerraPreta: UK

Traditional technologies

Caring for about cultural diversity is an essential aspect of sustainability. Traditional technologies and crafts are important components of technology education classrooms. The relationships between technology and the environment in a specific context can provide a rich source of knowledge and understanding on how to live in harmony with the natural environment. It is important to analyse culturally rooted technological decisions to appreciate their appropriateness as they accounts for the environmental, cultural, social and economic aspects of the community they are intended for. The concept of appropriate technology gained impetus with Schumacher's book Small is Beautiful (1973), where eight criteria were formulated for assessing technology:

\footnotetext{
${ }^{1}$ An extract from Webster \& Johnson (2008).
} 
1. Appropriate technology best suits the needs and lifestyle of the users.

2. Appropriate technology should not damage the environment and ecosystem and should be sustainable.

3. Appropriate technology should keep costs within the economic means of a community.

4. Appropriate technology should use locally available resources as far as possible.

5. Appropriate technology should enable local workers to earn a living.

6. Appropriate technology should increase self-reliance.

7. Appropriate technology should use renewable sources of energy wherever possible and should be economical in its use of non-renewable resources.

8. Appropriate technology should fit with its social and cultural environment.

These principles consider the social, environmental and economic sustainability of technologies. Appropriate technology explores what appropriate indigenous practices and technologies exist regionally, by developing and adapting these and by incorporating new ideas. Low cost solutions to local problems could be found without resorting to expensive and often inappropriate imported technologies. Regional appropriate technology organisations in Africa (http://www. approtechafrica.com/), Asia (http://www.atasia.org.uk/ata.aspx) and Australia (http://www.icat.org.au/) develop technology to empower people. They formulate their own interpretations of appropriate technology and examples from the web sites could be used by technology teachers to discuss and develop appropriate design solutions through technology education activities.

Eco-design

A number of eco-design principles, such as:

- Select low-impact materials

- Avoid hazardous materials

- Choose cleaner production processes

- Maximise energy and water efficiencies

- Design for waste minimisation

are used by professional designers and could be used in technology education classroom. These principles could be used in different ways at the stage of product design: ideas development, research, evaluation of ideas, during product analysis and so on. They are aimed to design for use of organic materials that are recyclable or compostable, or are made from minerals that are continuously cycled in a close loop; the products should be non-toxic in use and disposal and its manufacture does not involve toxic releases or the disruption of ecosystem; less materials, energy, water should be used during production and use, and the product should use solar energy or 
ESD through Technology Education: Contextualisation of Approaches

other forms of renewable energy both during use and manufacture. Different collections of green products are available on the internet that could be used as teaching resources in the classroom. For example, Datschefski (2011) identified the world's top 40 Greenest Products on his biothinking site (http://biothinking.com/top40.htm). These examples could be used to inspire students to find greener solutions for real needs. The products are chosen mainly because they are significantly better than "standard" products that do the same things. They are also in production, available for sale and have excellent functional performance.

Teachers can use these and other activities to include ESD in technology education classroom. Whether they put the main emphasis on the environmental or social aspect depends on the context they are operating in. Weak anthropocentrism will serve as an overarching thinking behind curriculum development that needs to consider the importance of value change and technical solutions to the existing problems.

\section{Conclusions}

This article argues for the need to frame teachers' personal subject construct by the notion of sustainable development that is interpreted as a concern for the human condition. The relationship between education for sustainable development and transformative pedagogy is established to highlight the role of human consciousness in the way global problems could be resolved, and a vital role of education in shaping a 'frame of mind' approach to sustainability.

Two essential bases for ESD pedagogy in technology education have been discussed to argue for:

- weak anthropocentrism as the ethics behind the ESD that focuses on human well-being to be achieved in harmony with nature; and

- a combination of value change and technical fix approaches to be used in technology education classroom.

In terms of classroom activities, environmental and social emphases were identified as possible priorities within different contexts. The argument was supported by the UNEP analysis of challenges confronted by countries internationally in terms of reducing per capita ecological footprint or increasing the human development index. Several examples of classroom activities illustrate how the above differences could be addressed in the class. 


\section{References}

Argyris, C., \& Schön, D. A. (2004). Organizational learning II: Theory, method and practice. In W. Scott \& S. Gough (Eds.), Key issues in sustainable development and learning: A critical review (pp. 63-68). London: Routledge Falmer.

Beck, U. (1994). Self-dissolution and self-endangerment of Industrial society: What does this mean? In U. Beck, A. Giddens, \& S. Lash (Eds.), Reflexive modernization: Politics, tradition and aesthetics in the modern social order (pp. 174-183). Cambridge: Polity Press.

Beck, U. 1997. The reinvention of politics: Rethinking modernity in the global social order. Cambridge: Polity Press.

Bonnett, M. (2002). Education for sustainability as a frame of mind. Environmental Education Research, 8(1), 9-20.

Cochran, K. F., DeRuiter, J.A., and King, R.A. (1993). Pedagogical content knowing: As Integrative Model for Teacher Preparation. Journal for Teacher Education 44, 263-272.

Datschefski, E. (2011). Biothinking. Retrieved on March 7, 2008, from http://biothinking.com/top 40.htm.

EarthTrends. (2008). Environmental information. http://earthtrends.wri.org/.

Ellul, J. 1990. The technological bluff [Trans. G.W. Bromiley]. Grand Rapids, Michigan: W.B. Eerdmans. (Original work published 1987).

Finnish National Commission on Sustainable Development, Sub-committee for Education. (2006). Strategy for education and training for sustainable development and implementation plan 2006-2014. Helsinki: Author.

Gardner, G. (2001). Accelerating the shift to sustainability. In L. Brown (Ed.), State of the world 2001. London: Earthscan Publications.

Giddens, A. (1990). The Consequences of modernity. Stanford, CA: Stanford University Press.

Giddens, A. (1994a). Living in a post-traditional society. In U. Beck, A. Giddens, \& S. Lash (Eds.), Reflexive modernization: Politics, tradition and aesthetics in the modern social order (pp. 56-109). Cambridge: Polity Press.

Giddens, A. (1994b). Risk, trust, reflexivity. In U. Beck, A. Giddens, \& S. Lash (Eds.), Reflexive modernization: Politics, tradition and aesthetics in the modern social order (pp. 184-197). Cambridge: Polity Press.

Habermas, J. (1971). Toward a rational society [Trans. J.J. Shapiro]. London: Heinemann. (Original work published 1968). 
ESD through Technology Education: Contextualisation of Approaches

Hart, P. (2008). Ontological/epistemological pluralism within complex contested EE/ESD landscapes: Beyond politics and mirrors. In E. González-Gaudiano \& M. A. Peters (Eds.), Environmental education: Identity, politics and citizenship (pp. 25-38). Rotterdam: Sense.

Huckle, J. 2006. Education for sustainable development: A briefing paper for the Training and Development Agency for Schools. http://john.huckle.org.uk/download/2708/Educa tion\%20for\%20Sustainable\%20Development,\%20a\%20briefing\%20paper\%20for\%20t he $\% 20$ Teacher\%20Training\%20Agency.doc.

IUCN, UNEP, \& WWF. (1991). Caring for the Earth: A strategy for sustainable living. Switzerland: IUCN.

Lundegård, I., \& Wickman, P-O. (2007). Conflicts of interest: An indispensable element of education for sustainable development. Environmental Education Research, 13(1), 115.

Marashian, A. (2006). Design for life. Another Magazine for Men and Women, 10, 136.

Pavlova, M. (2009). Conceptualisation of technology education within the paradigm of sustainable development. International Journal of Technology and Design Education, 19, 109-132.

Population Action International. (2008). Retrieved on 14 January 2008, from http://www.populationaction.org/.

Robinson, J. (2004). Squaring the circle? Some thoughts on the idea of sustainable development. Ecological Economics, 48, 369-384.

Schumacher, E. F. (1973). Small is beautiful: A study of economics as if people mattered. London: Blond \& Briggs Ltd.

Sterling, S. (2001). Sustainable education, re-visioning learning and change. Dartington: Green Books.

Sterling, S. (2004). Sustainable education: Re-visioning learning and change. Schumacher Briefings No. 6. Devon: Green Books.

Sterling, S. (2007) From the push of fear, to the pull of hope: Learning by design. Southern African Journal of Environmental Education, 24, 30-34. Retrieved 12 March 2010, from http://www.eeasa.org.za/index.php?option=com_content\&view=article\&id=64:so uthern-african-journal-of-environmental-education-volume-24-2007\&catid=45:journal s\&Itemid $=72$.

Stevenson, R. B. (2006). Tensions and transitions in policy discourse: Recontextualizing a decontextualized EE/ESD debate. Environmental Education Research, 12(3-4), 277290. 
United Nations. (1972). Declaration of the United Nations Conference on the Human Environment. http://www.unep.org/Documents.Multilingual/Default.asp?DocumentID $=97 \&$ ArticleID $=1503$.

United Nations. (1987). Our Common Future, Report of the World Commission on Environment and Development. Published as Annex to General Assembly document A/42/427. http://www.un-documents.net/wced-ocf.htm.

United Nations. (1992, June). Rio Declaration on Environment and Development. Presented at the United Nations Conference on Environment and Development (UNCED), Rio de Janeiro, Brazil. http://www.un.org/documents/ga/conf151/aconf15126lannex1.htm.

UNEP (2011). Towards a Green Economy: Pathways to Sustainable Development and Poverty Eradication. Access from www.unep.org/greeneconomy, June 2011.

UNESCO. (1969). Final report.I Intergovernmental conference of experts on the scientific basis for rational use and conservation of the resources of the biosphere, Paris, 4-13 September 1968. Document SC/MD/9. Paris: UNESCO. (http://unesdoc.unesco.org/im ages/0001/000172/017269eb.pdf.

UNESCO. (2005). United Nations decade of education for sustainable development 2005 2014. International implementation scheme. Paris: UNESCO Education Sector.

UNESCO. (2006). Framework for the DESD international implementation scheme. Paris: UNESCO Education Sector. (http://unesdoc.unesco.org/images/0014/001486/148650E .pdf).

Vernadsky, V.I. (1926). Biosfera (The Biosphere). In Russian. Leningrad: Nauka. (French version published in 1929.)

Vernadsky, V. I. (1945). The biosphere and the nöosphere. American Scientist, 33, 1-12. http://larouchepub.com/other/2005/site_packages/vernadsky/3207bios_and_noos.html.

Vernadsky, V.I. (1998). The Biosphere. Complete Annotated Edition. Copernicus/Springer Verlag, New York.

Webster, K. \& Johnson, C. (2008). Sense \& Sustainability: Educating for a low carbon world. TerraPreta: UK.

Worldwatch Institute. (2008). Vision for a sustainable world. Retrieved January 14, 2008, from http://www.worldwatch.org/taxonomy/term/109. 